\title{
EGFR Exon 18 Mutation
}

National Cancer Institute

\section{Source}

National Cancer Institute. EGFR Exon 18 Mutation. NCI Thesaurus. Code C128661.

A molecular genetic abnormality indicating the presence of a mutation in exon 18 of the EGFR gene. 